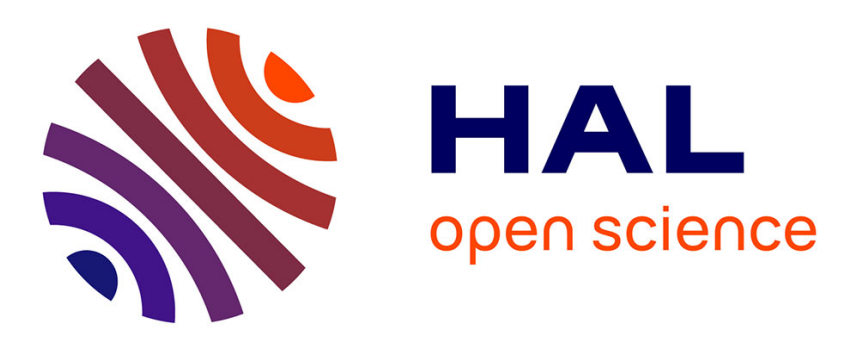

\title{
In situ characterization of flows in a fractured unstable slope
}

Stéphane Binet, Jacques Mudry, Claudio Scavia, Stefano Campus, Catherine Bertrand, Yves Guglielmi

\section{- To cite this version:}

Stéphane Binet, Jacques Mudry, Claudio Scavia, Stefano Campus, Catherine Bertrand, et al.. In situ characterization of flows in a fractured unstable slope. Geomorphology, 2007, 86 (1-2), pp.193-203. 10.1016/j.geomorph.2006.08.013 . insu-00617251

\section{HAL Id: insu-00617251 \\ https://hal-insu.archives-ouvertes.fr/insu-00617251}

Submitted on 26 Aug 2011

HAL is a multi-disciplinary open access archive for the deposit and dissemination of scientific research documents, whether they are published or not. The documents may come from teaching and research institutions in France or abroad, or from public or private research centers.
L'archive ouverte pluridisciplinaire HAL, est destinée au dépôt et à la diffusion de documents scientifiques de niveau recherche, publiés ou non, émanant des établissements d'enseignement et de recherche français ou étrangers, des laboratoires publics ou privés. 


\title{
In situ characterization of flows in a fractured unstable slope
}

\author{
Stéphane Binet a,, Jacques Mudry a, Claudio Scavia b, Stefano Campus c, \\ Catherine Bertrand a, Yves Guglielmi d
}

a EA 2642 Géosciences University of Franche-Comté 16 route de Gray 25000 Besançon, France E-mail address: stephane.binet@ univfcomte.fr (S. Binet).

b Politecnico di Torino C.so Duca degli Abruzzi 2410129 Torino, Italy

c ARPA C.so Unione Sovietica 21610134 Torino, Italy

d CNRS UNSA, 250 rue Albert Einstein Sophia Antipolis 06560 Valbonne, France

\begin{abstract}
In the case of large unstable mountain slopes, the spatial repartition of the saturated zones influence the pressure repartitions in the massif and the slope stability. This contribution proposes an evaluation of water origin and pressure transit time of roundwater flows fromhydrochemical and isotopic measurements. The objective is to propose a conceptualmodel of the groundwater flows and a location of the saturated zones in the slope. The interpretation of time measurements of water pressure in the collapsed zone highlights (i) an evolution of flows with deformation that induces a damaging of the rock properties and (ii) the necessity to connect hydrogeological conditions and geological background in a dynamical system to analyse the pore pressure in the fractured collapsed zone.
\end{abstract}

\section{Introduction}

In the case of large unstable mountain slopes, clearly the main driving force of instability is gravity and the major triggering factor is groundwater (Noverraz et al., 1998). For example, after a hydrogeological study on the Vallemaggia landslide, Bonzanigo et al. (2001) prove that, by draining the massif, the pore water pressure in the unstable slope is the main factor that triggered the unstable mass velocity increases, and now, under dry conditions, the slope is stable. In an unstable fractured massif, flows create pore water pressure variations that trigger the landslide acceleration. However, in mountainous slopes infiltration events are heterogeneous, with important elevation variations, created by rain and temperature variability. After infiltration, water flows within the metamorphic rocks and can be drained through perched aquifers in the uncompressed or weak fault zones (Maréchal, 1998). Finally groundwaters flow through the heterogeneous slope in a multipermeable fractured media, where permeability ranges from 10-11 m/s in the gneiss matrix to $10-3 \mathrm{~m} / \mathrm{s}$ in the fractures (Cappa et al., 2004) to flow in the landslide where rock permeability is not constant but is a function of stress and stress induced damage (Tang et al., 2002). Thus, to study the mechanisms that influence the water effect on landslide acceleration, a model of flow in the slope is necessary.

To understand these complex flows a hydrogeochemical approach is applied from the La Clapière slope (Guglielmi et al., 2000, 2002; Cappa et al., 2004 Guglielmi et al., 2005) to the Rosone slope (Piemont, Italy). The water flow path and saturated zone in this slope are localized with a detailed hydrogeological investigation and geochemical measurements, coupled with time evolution of pore water pressure and deformation in the slope, recorded over 4 yr. These data enable us to propose a conceptual model of flow in an unstable area in a dynamical system.

\section{Geomorphology of the Rosone slope}

This rock slope, which mainly consists of gneiss, is located on the Italian side of the Western alps and has been affected by recurrent instability phenomena. The entire southern side of the ridge bounded by the Orco and Piantonetto Rivers has been undergoing a slow process of gravitational slope deformation (Fig. 1). The entire slope ranges from 700 to $2000 \mathrm{~m}$ asl. Located in the metamorphic rock of the "Gran Paradiso" units, movements affect about $5.5 \mathrm{~km} 2$ area and reach depths of over $100 \mathrm{~m}$ (Forlati et al., 2001). The characterization of rock mass shows three main systems of discontinuities, the schistosity (dip direction of $154^{\circ}$, dip of $34^{\circ} \mathrm{S}$ ), and two main joint sets (dip direction of $20^{\circ}$, dip of $86^{\circ} \mathrm{W}$ and dip direction of $100^{\circ}$, dip of $68^{\circ} \mathrm{N}$, Fig. 8) (Forlati et al., 2001). These discontinuities drive the gravitational movements and create a high heterogeneity in rock properties (Forlati et al., 2001). The morphological and structural characteristics of the area and the annual average motions suggest subdividing it into three sectors, corresponding roughly to the villages of Ronchi, Perrebella, and Bertodasco (INTERREG1, 1996). A $17 \mathrm{~km}$ water pipe spanning is drilled in the entire length of the gravitational deformation (Fig. 1, noted CF in hydrochemical analysis). With the objective to investigate the possible modes of instability of the rock slope, by using a discontinuous model, Barla and Chiriotti (1995) show that with the unloading process which occurswith deglaciation, the rock mass at the crest of the slope undergoes failure in shear (as shown by the cross section in Fig. 8) and creates uncompressed zones at the crest. The uncompressed zone is composed of a $3 \mathrm{~km} 2$ toppled zone (Perrebella and Ronchi) with centimetric open fractures, ranging from 1400 to 2000masl., high fractured trenches and zones with unweathered gneiss (Fig. 3). 
Based on morphological, structural characteristics, inclinometric measurements, surface deformation measurements, seismic imaging and laboratory tests, a detailed hazard analysis of the collapsed zone is developed (Amatruda et al., 2004). The analysis defined three zones in the collapsed zone with different average annual velocities (Fig. 1) that represent three scenarios of rupture with different involved volumes: (i) the collapse of the heavily fractured zone $\mathrm{C}$ (Fig. 1), therefore continuous rockfalls can weaken the rock mass located in this sector, (ii) the collapse of the zone $\mathrm{C}$ may bring about the avalanche of zone $\mathrm{B}$ at the same time. The volume involved would be about 9,300,000 $\mathrm{m}_{3}$ (Amatruda et al., 2004), (iii) collapse of the whole landslide area, zones $\mathrm{C}$ and B may induce the avalanche of the whole rock body involving a volume of about 20,500,000 m3. A number of factors that could affect the stability conditions of the slope were evidenced. Geological structure and transient water pressures are the predominant factors for slope stability (Barla and Chiriotti, 1995). To get some insight into the causes of the phenomenon, a series of non-linear, time-dependent analyses has been carried out through the finite element method. The slow movement of the rock mass, and the gradual loss of its mechanical properties with increasing deformation, has been accounted for the calculations by means of a viscoplastic law, allowing for strain softening effects. The results of the analyses lead to some conclusions on the causes of the observed movements, among which the possible influence of the change of groundwater pore pressure during time is likely to play an important role on the observed movements. The interpretation of pore water pressure is not straightforward, due to the complex hydrogeological conditions of the slope. No reliable correlation has been established so far between the evolution of the hydraulic pressure during time and the amount of rainfall (Forlati et al., 2001).

We performed a new hydrogeochemical study at the landslide scale to characterize the relation between gravitational features and hydrogeology, to discuss origin of water in the landslide and the dynamical evolution of flows. The aim is to bring new data on the complex hydrogeological conditions of this unstable slope. Sacchi et al. (2004) have studied the hydrogeology and hydrogeochemistry of the Orco Valley to characterize past hydrothermal and present fluid circulation in the Gran Paradiso massif. These observations give a general conceptual model of flow in the stable fractured gneiss at the Gran Paradiso massif scale and give a valley scale model of flows in which our study takes place.

\section{Methods}

First, water chemistry is studied to inform us about the hydrogeological setting (Mudry et al., 1994; Guglielmi et al., 2002). An instantaneous physical and chemical analysis of all the springs that drain the Rosone slope has been performed in June and December. Cation measurements are made with the atomic absorption spectrophotometer PerkinElmer A analyst 100 and the anion measurement with a high pressure ionic chromatograph Dionex DX 100 (precision is about 5\% maximum, according to the dilution coefficient). Bicarbonate is measured volumetrically. The chemical content, interpreted like the result of water-rock interactions, enables to define several flow types that characterize the different water-rock interaction types. The comparison between water chemistry variability and geomorphological and geological maps defined several aquifer types, with different hydraulic properties. Second, the average elevation of the recharge area of water sampled is determined with an isotopic method (Fontes, 1976). The stable isotope of oxygen, $\delta 180$, is determined with a mass spectrometer MAT 250 Hausverfahren $( \pm 0.15 \delta 18 \mathrm{O})$ by Hydroisotop GmbH; the unit of measurement corresponds to a normalized value referred to the sea water value. In water of precipitations, $\delta 180$ content is controlled by climatic conditions and evapotranspiration. In mountainous areas, with an important temperature gradient with elevation, the $\delta 18 \mathrm{O}$ content (which is thermo-dependent and stable during infiltration time records the infiltration elevation of water; Razafindrakoto, 1988; Juif, 1991; Novel et al., 1995; Guglielmi et al., 2000; Maréchal and Etcheverry, 2003).

Third, an estimation of infiltrated water in the slope is performed using time measurements of rainfall, snow cover, and temperature measurements (Fig. 2). No runoff is considered in the uncompressed zone, because of the opening of fractures and the presence of counterscarps in the slope (Fig. 3), but in the strong slopes (N45\%) without deformation observations on the surface, the runoff is considered as draining all the superficial water. The daily Turc equation (De Marsily, 1981) is applied for rainfall. Using a $14 \mathrm{yr}$ long data set of 26 gauging stations in the central Italian Alps, it is considered that $1 \mathrm{~cm}$ of snow gave $1 \mathrm{~mm}$ of infiltrated water (Bocchiola and Rosso, in press).

During 2001, two water pressure tests (Lugeon Test) where realized in the collapse area. It consists of three 5minute water injections carried out at the same pressure. The hydraulic conductivity is measured in terms of Lugeon units, with 1 Lugeon Unit equals to a water take of $11 / \mathrm{m} / \mathrm{min}$ at a pressure of 10 bars. 1 Lugeon Unit is interpreted in the SI unit system with the approximate relationwhere $1 \mathrm{UL}$ corresponds to $2 \cdot 10-7 \mathrm{~m} / \mathrm{s}$ (De Marsily, 1981).

The monthly infiltrated water was compared to 4 yrs head evolution in the piezometer (B1) located in the collapsed zone C (Fig. 1) and compared to the surface movement gives information on the hydromechanical behaviour and enables us to examine the time evolution of the flows in the slope. 


\section{Results and interpretation: hydrogeology of the slope}

4.1. Relation between gravitational structures and hydrogeology

For infiltration conditions, the counterscarps strongly reduce the runoff and the high fracturing in the uncompressed zone induced heterogeneity of groundwater infiltration. Thus, water from Perrebella river (S4, Fig. 1) sinkholes in an uncompressed zone $50 \mathrm{~m}$ lower and the water of Bertodasco spring (S5) passes through a counterscarp (Fig. 4). On the entire slope, the uncompressed zones bound by an extrapolation of counterscarps and trenches, are represented in Fig. 4 and correspond to the recharge area.

The collapsed sector of Bertodasco, slides along a $0.95 \mathrm{~km} 2$ quasiplanar surface along the schistosity surfaces (Fig. 4). With movement of 7-21 mm/yr, the zone corresponds to the more collapsed zone $\mathrm{C}$ of Fig. 1. The foot of the Bertodasco sector (base of the movement) is a zone with a high density of springs with low water yield of $5 \mathrm{l} / \mathrm{s}$ (June 2004). Springs 18-19 have a yield around $20 \mathrm{l} / \mathrm{s}$ and are the main outputs in the slope (Fig. 4). The other springs located on the slope have low yields, less than $1 \mathrm{l} / \mathrm{s}$ each. The geometric correlation between outflowing springs and rupture surface measured in borehole demonstrates that the rupture surface is a draining zone.

An analysis of the Bertodasco zone hydrogeology is interpreted from detailed geomorphological investigations and borehole observations (Fig. 5a). The A1 drilling presents an alternation of soil and rock from 0 to $48 \mathrm{~m}$, and deeper the gneissic rock. The sliding surface is intercepted at $38.98 \mathrm{~m}$ (data from inclinometer), and the water level varies around a depth of 31 mabove the sliding surface. In the B1 drilling, the limit between alternating soil-rock and rock is $43.5 \mathrm{mdeep}$, with some uncompressed gneiss. The rupture surface is at $40.23 \mathrm{~m}$, and the water table in B1 varies around a depth of $47-54 \mathrm{~m}$, under the rupture surface (Amatruda et al., 2004). The geomorphologicalmap (Fig. 4) present scarps and counterscarps under the collapsed zone, crossing in the B1 drilling. The collapsed zone corresponds roughly to weathered gneiss (alternating rock and soil), and the saturated zone is located at the boundary of the gneissic rock (Fig. 5b). But with toppling, the rock is fractured and uncompressed in the trenches, like under the B1 borehole. The saturated zone, usually located at the boundary of the gneissic rock, can extend to the uncompressed gneiss. The springs located at the foot of the sliding mass do not have the same elevation that display heterogeneity of fracture orientations, with preferential flows in the sliding surface. Water, infiltrated in the uncompressed zone outward of the landslide can pass in the collapsed zones. Aquifer from uncompressed zones and aquifer from the collapsed zones are connected. The time evolution of this zone is discussed from extensometers and pore water pressure measurements in Section 5. The absence of water in the A2 borehole crossing the sliding surface (Figs. 1 and 8) suggests that the saturated zones are not continuous along the sliding surface. The presence of water in the A2, A1 and B1 borehole crossing the uncompressed zone, suggests that the saturated zones are concentrated in the more uncompressed zones in the trenches under the collapsed zone.

\subsection{Water origin and boundary conditions: spatial}

variations of water chemistry The chemical content of the springs draining the massif, analysed in June and November 2004, enables a classification of springs in three groups, showed by the relative percentage of each major ion (Piper plot, Fig. 6a): (i) magnesium potassium type and low mineralized water (ii) calcium bicarbonate type, and (iii) magnesium calcium type. These types are differentiated on the hydrogeological map (Fig. 4). The magnesium potassium and low mineralized water type is interpreted like short-termwater rock interactions and small superficial aquifers. The magnesium and the potassium are the most present ions but the concentrations are weak. These perched aquifers near the surface correspond to water in highly uncompressed zones. The springs with the calcium bicarbonate type are located in the glacial deposits composed of minerals that bring bicarbonate in water. The magnesium calcium type reflects to water rock interaction in fractured gneiss and includes most of the springs.

Interpretation of isotopic measurements is done at a local scale, using springs located between $1300 \mathrm{~m}$ and 2000 $\mathrm{m}$, whose recharge elevations are known (black squares in Fig. 4). The springs used for gradient calibration belong to the magnesium potassium water type presented in Fig. 4, corresponding to superficial aquifers, where recharge areas are easy to define with cartographic data. The $\delta_{18} \mathrm{O}$ gradient obtained for November 2004 is about $0.26 \% / 100 \mathrm{~m}$. The range of annual and spatial variations of $\delta_{18} \mathrm{O}$ gradient are estimated by comparison with other gradients measured in similar climatic contents (Juif, 1991; Guglielmi et al., 2000; Maréchal and Etcheverry, 2003), this range defines an error range (Fig. 6b) due to seasonal temperature variations. Thus, most of the sampled springs in the foot of the valley have a conductivity b60 mS/cm2 and a $\delta_{18} \mathrm{O}$ content comparable to water infiltrated at mean elevation of the recharge area around $1800 \mathrm{~m}$, correlated with the uncompressed zone of Ronchi (Fig. 3). The Ronchi zone is the recharge area for most of the springs of the slope. Spring S11, outflowing from a glacial deposits, presents an infiltration elevation of $1800 \mathrm{~m}$. This is an overflow of water passing through the Bertodasco instability. Most of the water flows directly into the debris flows and in the alluvium of the Orco River. The water budget is difficult to measure. The average recharge area for sources 3, 6 
and 9 inferred from the calibration average recharge area of about $2000 \mathrm{~m}$, may be explained as a mix with the water from the $17 \mathrm{~km}$ pipe $(\mathrm{CF})$.

\subsection{Water budget}

The infiltration yields per surface unit have been defined for each spring, with a well defined recharge area, and compared to low water yield (Table 1). Data give an infiltration yield of about $3.1 \mathrm{l} / \mathrm{s} / \mathrm{km}_{2}( \pm 0.4)$. Spring S5, with a $0.06 \mathrm{~km} 2$ infiltration area relative to the sliding area bounded between $1500 \mathrm{~m}$ and $1175 \mathrm{~m}$, presents an infiltration yield about $9 \mathrm{l} / \mathrm{s} / \mathrm{km} 2$. If we hypothetically increase the size of the recharge (area including the S4 area) taking into account that the water of spring S4, sinkholes in a trench and flows in the sliding mass, the new infiltration surface is about $0.17 \mathrm{~km} 2$ and the infiltration yield becomes $3.1 \mathrm{l} / \mathrm{s} / \mathrm{km} 2$, which is more coherent with the other springs (S4, S15, S16, S20, Table 1).

\subsection{Hydraulic properties of the aquifers}

The time measurements are analysed to estimate transfer time between an infiltration period and a water pressure increasing in the B1 borehole (Fig. 7). This transfer time characterizes the flow in the uncompressed zone. Related to the infiltration intensity, the pore water pressure in the collapsed zone increases after $1.4 \mathrm{~d}$ after an infiltration event. The permeability, calculated from a Lugeon test that is performed in two points of the collapsed zone, enables us to estimated permeability of the perched aquifer. These data are plotted in the cross section (Fig. 8). The permeability ranges from $1.510_{-5}$ to $2.510_{-6} \mathrm{~m} / \mathrm{s}$ in the collapsed zone.

\section{Discussion}

\subsection{Conceptual model of groundwater flow}

Fig. 8 shows a hydrogeological cross section of the Rosone slope, with uncompressed zones that are interpreted from numerical calculations where failure occurs, as the unloading process due to deglaciation takes place (Forlati et al., 2001). The springs with a magnesium potassium type (Fig. 6a) are draining perched aquifers in the uncompressed and collapsed zones. The magnesium potassium type is a marker of fractured aquifers. These contrasted chemical types show that the perched flows are not mixed with water from the fractured rock during a low water table period. Thus a model with perched saturated zones disconnected from the fractured aquifer is more appropriate. Two different aquifers take place in the fractured gneiss and in the uncompressed zone.

The interpretation of $\delta_{18} \mathrm{O}$ data suggests the uncompressed zone as a recharge area, and the field observations show a relation between counterscarp and sinkhole. Gneiss has a low permeability, so open fractures are the main ground water drains. The spring location shows that the groundwater flow paths are strongly controlled by trenches and sliding surfaces. This correlation is validated by drilling data, recording saturated zones in the uncompressed volumes (A101, A1, B1) and unsaturated zones between the uncompressed volumes (A2) (Fig. 8). Water from the perched aquifer can flow to the fractured one, as it is suggested by $\delta_{18} \mathrm{O}$ values of the fractured gneiss springs (S18-19).

The water in several saturated zones in trenches flow into more uncompressed zones parallel to the slope with underground runoff or somewhere by a spring-sinkhole system, such as the S4 or S5 river (Figs. 4 and 5). Water flows in the sliding surface only around these trenches. Connections between the trenches are possible using unsaturated flows. The high density of springs in the collapsed zone and the yields of 0.5 to $1.5 \mathrm{l} / \mathrm{s}$ measured at the no. 5 spring suggest an infiltration area wider than the collapsed zone itself. The infiltration yields (Table 1) known only for perched water demonstrate the connection between moving mass and trenches outside of the collapsed zone. Water pressure measurements in A1 and B1 suggest the same behaviour model for the trenches above the S5 springs. The flow model is coherent with the conceptual model of the present groundwater circulation at the Orco Valley scale proposed for deep water flowanalyses (Sacchi et al., 2004). Moreover, most landslides have an important natural shallow drainage system, which is supplied to the deeper groundwater table (Van Asch et al., 1999).

\subsection{Slope diffusivity evolution}

Fig. 5 presents the instrumentation installed in the Bertodasco sector. The head measurements in the B1 borehole are plotted in Fig. 9 with the opening of the extensometer 5 considered as representative of the zone $\mathrm{C}$ movements compared to other extensometers and inclinometers. The minimum head in the massif seems to decrease with time. In 2001, a long low water period of about $30 \mathrm{~d}$ without infiltration recorded a minimum head of $6.6 \mathrm{~m}$, whereas in 2003 the minimum head was $4.2 \mathrm{~m}$. Such differences can originate from differences in infiltrated volume or from diffusivity variation in the aquifer, which reduce the pressure transfer duration (Van Asch et al., 1999). To discuss the evolution of head during a low water period, the maximum head after precipitation in the Rosone slope is compared with infiltration water accumulated in one month. The one month duration is chosen relatively to transfer time estimated in the B1 borehole (Fig. 7) between 10 and $30 \mathrm{~d}$ to evacuate water pressure from a precipitation event and to evacuated prestorm saturation of porosity in the slope. 
The results are presented in Fig. 10 which presents maximum head in the piezometer as a function of infiltrated water. The relation between the maximum head recorded during an infiltration event and the infiltrated water that induces this precipitation event presents a decrease of pressure in time that is affected by a period of high collapse movements. The movement of the collapsed zone creates deformations in the material, thus creates damage and irreversible modifications in groundwater flows (Tang et al., 2002).

For the same infiltration rate, the pressure increase is higher before 5th May 2001 compared to 2003. Thus, to explain this evolution, two hypotheses are possible: a diminution of the size of the infiltration area or an evolution of diffusivity in the sliding mass. As it is proved that the Bertodasco sector is connected with the entire toppling area, the variation of water pressures are attributed to an evolution of diffusivity in the massif, occurring quickly after a movement of the slope, because the overall permeability of a fractured rock increases with the increasing of fracture density (Zhang and Sanderson, 1998). This phenomenon of head decrease with instability is observed in some superficial landslides. The drainage by fissures results in a lower spatial average height of the groundwater table. However in the collapsed zones, the instability is initiated early and more often. A more rapid access of rainwater and a more rapid drainage by the fissure system cause higher temporal frequency instability (Van Asch et al., 1999).

\section{Conclusion}

In the Rosone slope, hydrochemistry analysis shows two main systems of water: perched water and water flowing through fractures. Isotopic measurements demonstrate that the importance of an area ranging around $1800 \mathrm{~m}$ is strongly correlated with the mapped uncompressed zone. The perched water flows in an uncompressed zone and passes into the collapsed zone. The hydrogeology of the slope is driven by instability features. In the collapsed zone, the flows evolve with deformation evolution. The water pressure measurements in the collapsed zone enable us to characterize a damage effect on groundwater flows. Following a short deformation event, about $1 \mathrm{~mm} / \mathrm{d}$, the hydraulic massif properties are definitely modified. The groundwater flows in the slope are time-dependent, with a rapid evolution during a period of high collapse movements. The prediction of the water pressure effect on the movement requires a quantification of the evolution of rock properties having experienced a deformation.

\section{Acknowledgements}

This work is supported by the French and Italian University. We sincerely thank the ARPA of Torino for their collaboration.

\section{References}

Amatruda, G., Campus, S., Castelli, M., Piane, L.D., Forlatti, F., Morelli, M., Paro, L., Piana, F., Pirulli,M., Ramasco,M., Scavia, C., 2004. The Rosone landslide. In: Bonnard (Ed.), Identification and Mitigation of Large Landslide Risks in Europe. IMIRILAND PROJECT,A.A. Balkema Publishers, Leiden,Germany, pp. 89-136.

Barla, G., Chiriotti, E., 1995. Insights into the behaviours of the large deep seat gravitational slope deformation of Rosone, in the Piemont region (Italy). Felsbau 13 (6), 425-432.

Bocchiola, D. Rosso, R., in press. The distribution of daily snow water equivalent in the central Italian Alps. Advances in Water Resources. Bonzanigo, L., Eberhart, E., Loew, S., 2001. Hydromechanical factors controlling the creeping Campo Vallemaggia landslide, In Symposium of Landslides (Ed.), Causes, Impacts and Countermeasures, June 2001, Davos, Switzerland pp. 9-12.

Cappa, F., Guglielmi, Y., Soukatchoff, V.M., Mudry, J., Bertrand, C., Charmoille, A., 2004. Hydromechanical modeling of a large moving rock slope inferred from slope levelling coupled to spring long-term hydrochemical monitoring: example of the La Clapiere landslide (Southern Alps, France). Journal of Hydrology 291 (1-2), 67-90.

De Marsily, G., 1981. Hydrogéologie Quantitative. Masson, Collection Sciences de la Terre, Paris, France.

Fontes, J., 1976. Les isotopes dumilieu dans les eaux naturelles, vol. 3/4. La Houille blanche, pp. 205-221.

Forlati, F.,Gioda, G., Scavia, C., 2001. Finite element analysis of a deepseated slope deformation. Rock Mechanics and Rock Engineering 34, 135-159.

Guglielmi, Y., Bertrand, C., Compagnon, F., Follacci, J.P., Mudry, J., 2000. Acquisition of water chemistry in a mobile fissured basement massif: its role in the hydrogeological knowledge of the La Clapiere landslide (Mercantour massif, southern Alps, France). Journal of Hydrology 229 (3-4), 138-148.

Guglielmi, Y., Vengeon, J.M., Bertrand, C., Mudry, J., Follacci, J.P., Giraud, A., 2002. Hydrogeochemistry: an investigation tool to evaluate infiltration into largemoving rockmasses (Case study of the La Clapière and Séchilienne alpine landslides). Bulletin of Engineering Geology and Environment 61, 311-324.

Guglielmi, Y., Cappa, F., Binet, S., 2005. Coupling between hydrogeology and deformation of mountainous rock slopes: insights from La Clapière area (Alpes Maritimes). Comptes Rendus Geosciences 337 (13), 1154-1163. INTERREG1, 1996. Risques générés par les grands mouvements de versant, étude comparative de 4 sites des Alpes franco-italiennes. Programm France-Italie. Regione piemonteuniversity J. Fournier, Grenoble, 207 pp.

Juif, L., 1991. Hydrologie de la haute montagne. Approche du fonctionnement hydrodynamique des aquifères de Vanoise, Phd thesis, Université de Franche-Comté, Besançon, France, 257 pp.

Maréchal, J.C., 1998. Les circulations d'eau dans les massifs cristallins alpins et leurs relations avec les ouvrages souterrains. Phd thesis, Ecole Polytechnique Fédérale de Lausanne, Switzerland, 295 pp.

Maréchal, J.C., Etcheverry, D., 2003. The use of 3H and $18 \mathrm{O}$ tracers to characterize water inflows in Alpine tunnels. Applied Geochemistry 18 (3), 339-352.

Mudry, J., Lastennet, R., Puig, J., Blavoux, B., 1994. Use of natural tracing to understand how an aquifer works. Basic and applied hydrogeological research in French Karstic areas. In: Crampon, N., Bakalowicz, M. (Eds.), COST, vol. 65. Brussels, Belgium. 27-53 pp. 
Novel, J.P., Ravello, M., Dray, M., Pollicini, F., Zuppi, G.M., 1995. Contribution isotopique (18O, 2H, 3H) a la compréhensoin des mécanismes d'écoulements des eaux de surfaces et des eaux souterraines en vallée d'Aoste (Italie). Geografia Fisica e Dinamica Quaternaria $18,315-319$

Noverraz, F., Bonnard, C., Dupraz, H., Huguenin, L., 1998. Grands Glissements de Versants et Climat, vdf Hochschulverlag AG an der ETH, Zurick, Switzerland. Razafindrakoto, S., 1988. Teneurs en isotopes stables des précipitations et des eaux souterraines et leurs variations en France, Phd thesis, Université d'Avignon et des Pays de Vaucluse, Avignon, vol.1, 89p-vol.2, 350 pp.

Sacchi, E., Dematteis, A., Rossetti, P., 2004. Past and present circulation of $\mathrm{CO}_{2}$-bearing fluids in the crystalline Gran Paradiso Massif (Orco Valley, north-western Italian Alps): tectonic and geochemical constraints. Applied Geochemistry 19 (3), 395-426.

Tang, C.A., Tham, L.G., Lee, P.K.K., Yang, T.H., Li, L.C., 2002. Coupled analysis of flow, stress and damage (FSD) in rock failure. International Journal of Rock Mechanics and Mining Sciences 39 (4), 477-489.

Van Asch, T.W.J., Buma, J., Van Beek, L.P.H., 1999. A view on some hydrological triggering systems in landslides. Geomorphology 30

(1-2), 25. Zhang, X., Sanderson, D.J., 1998. Numerical study of critical behavior of deformation and permeability of fractured rock masses. Marine and Petroleum Geology 15 (6), 535-548. 


\section{FIGURES AND TABLES}

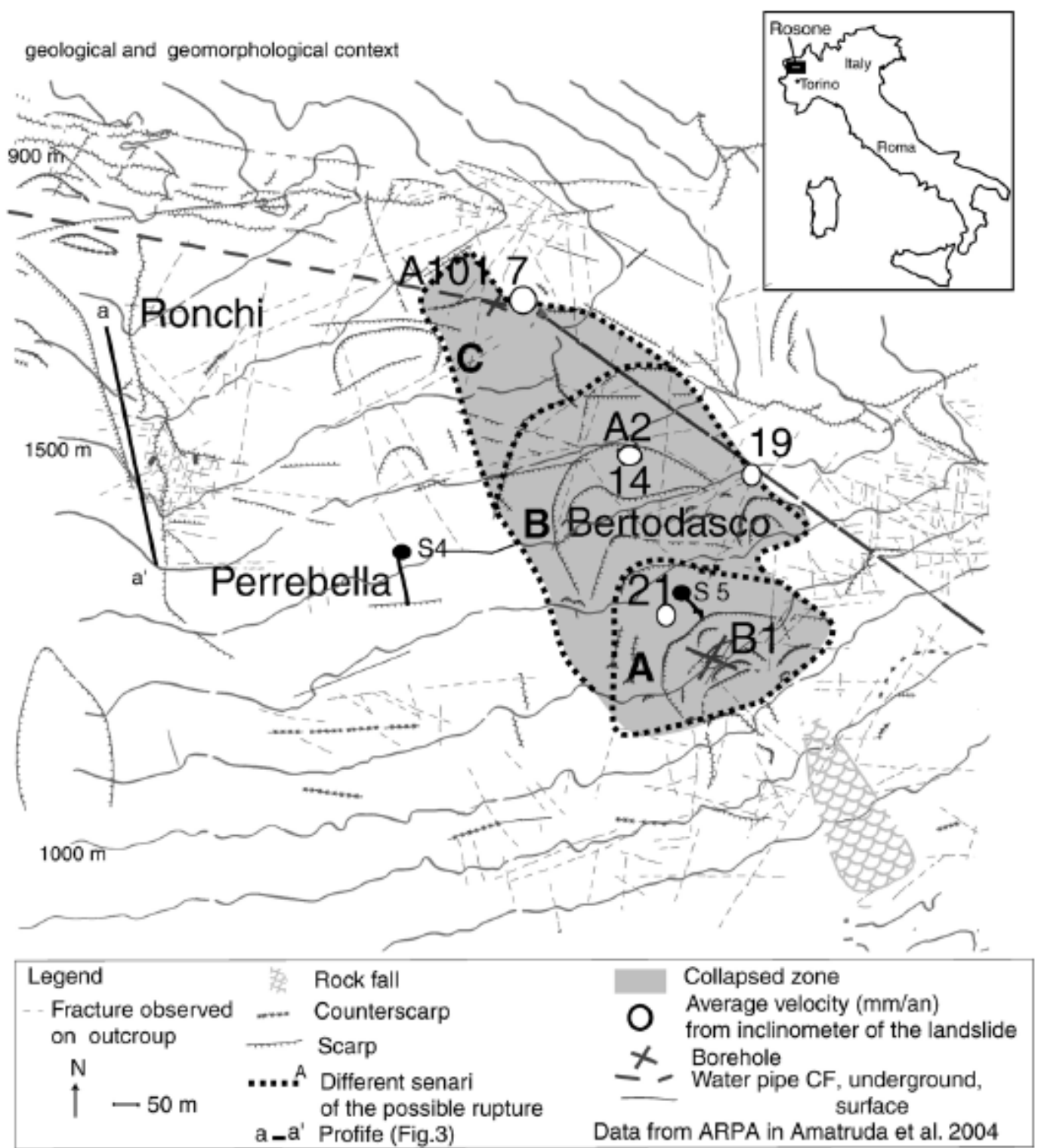

Fig. 1. Geologic and geomorphologic setting of the Rosone slope

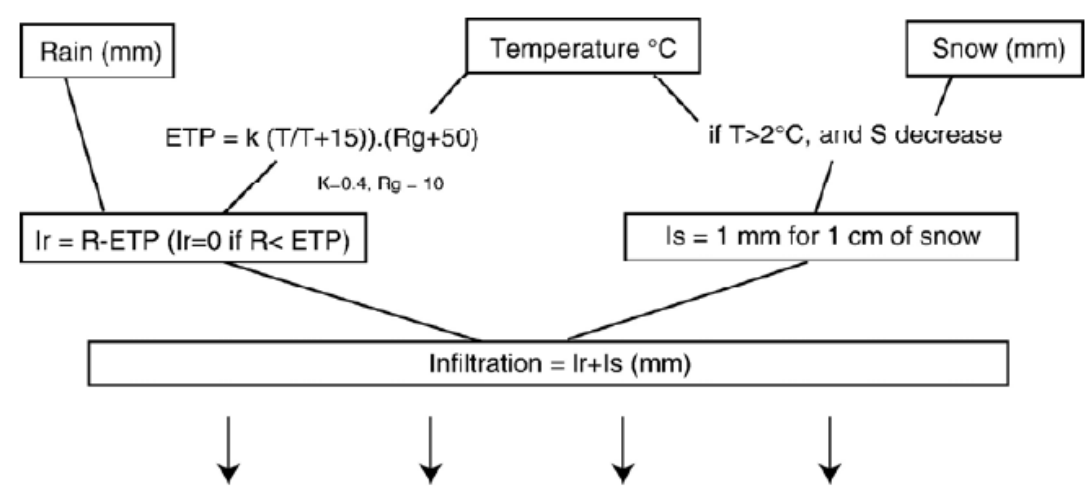

Fig. 2. Protocol to estimate infiltrated water on the slope and to estimate hydrodynamic parameters. 


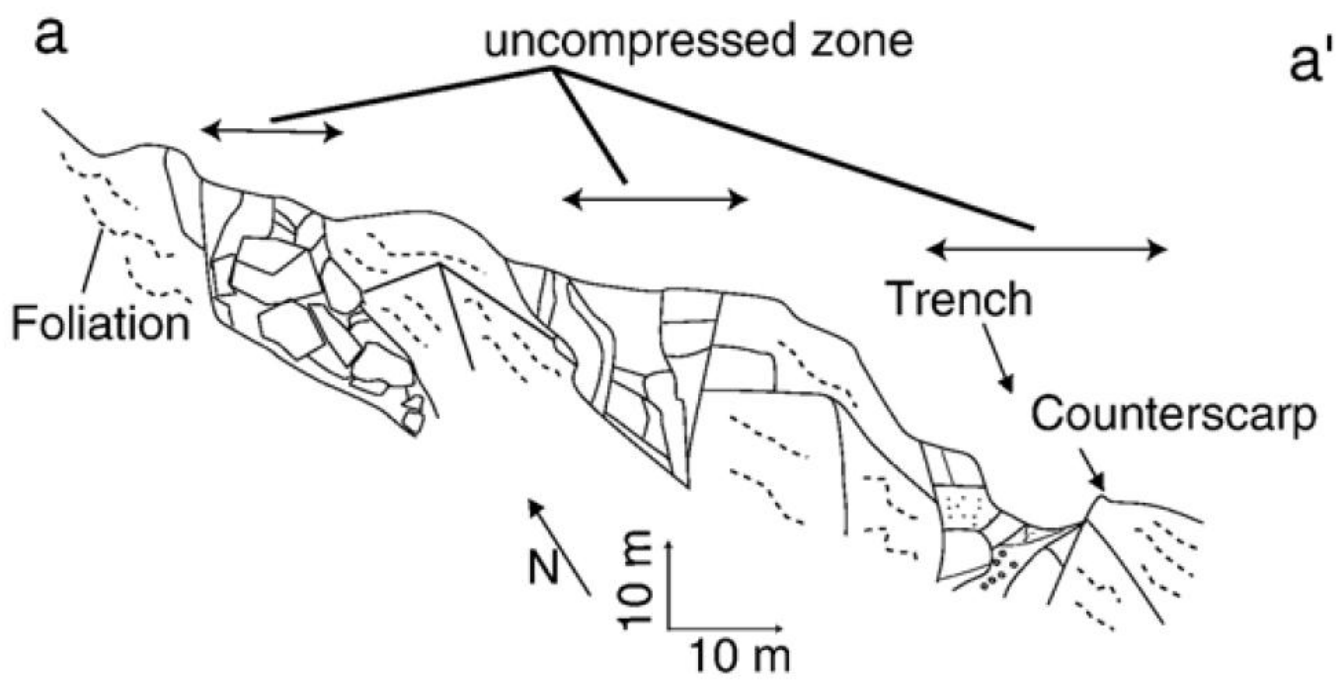

Fig. 3. Schematical view of the main scarp in the Rosone slope from a photo.

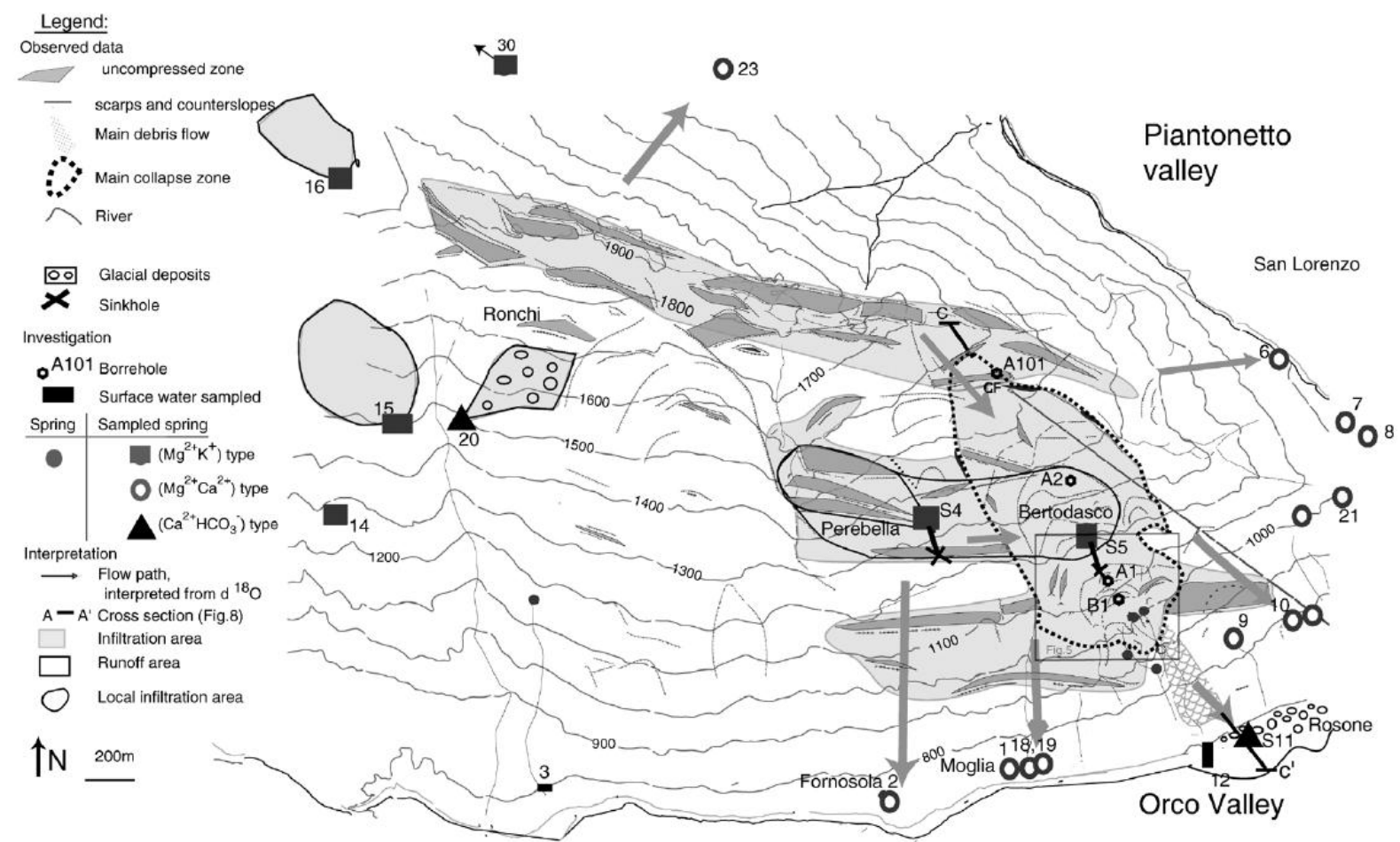

Fig. 4. Hydrogeology of the Rosone slope, map of the slope with recharge area, uncompressed zones, and a classification of the water chemical results. 


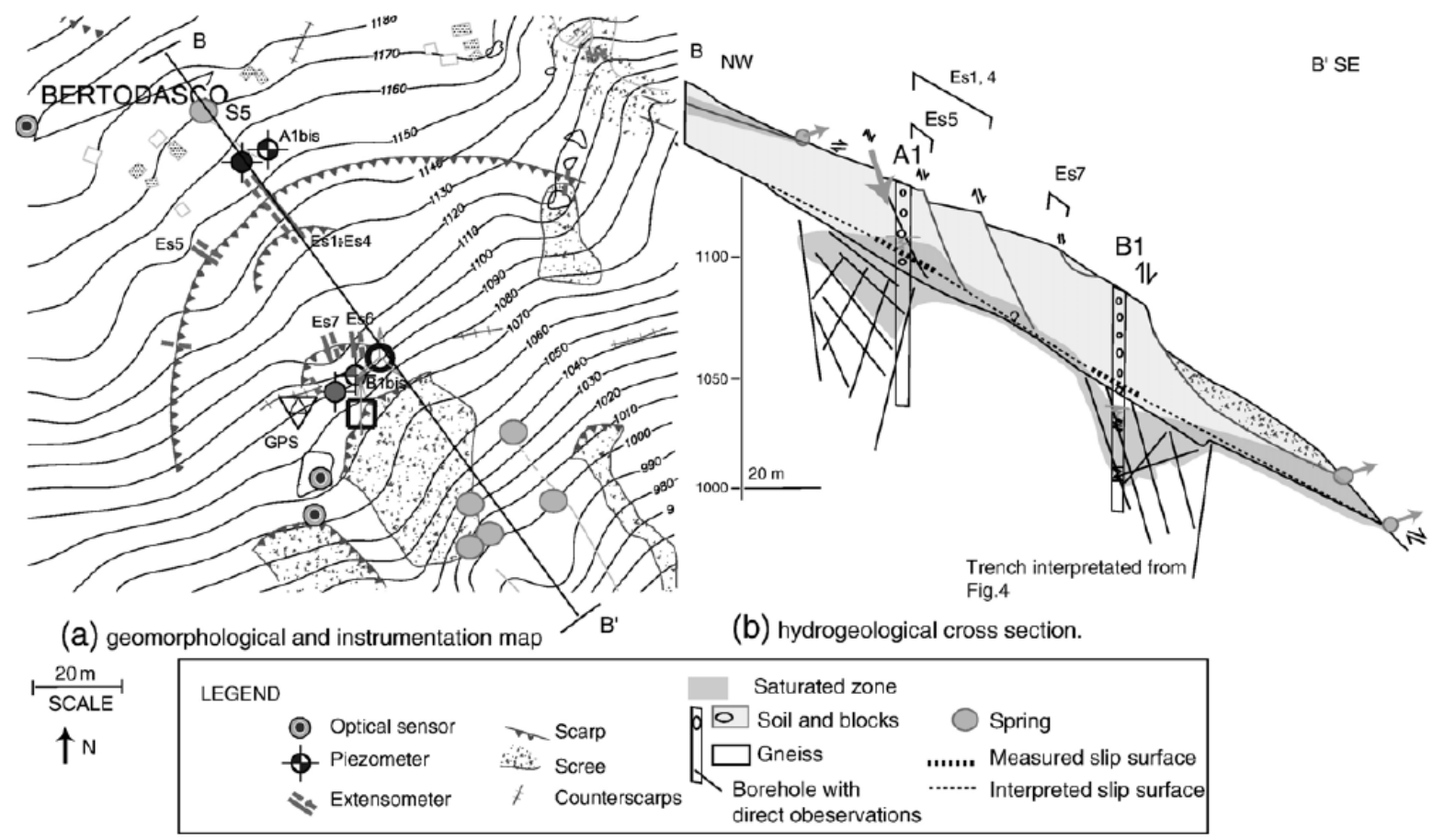

Fig. 5. Detail of the Bertodasco sector.

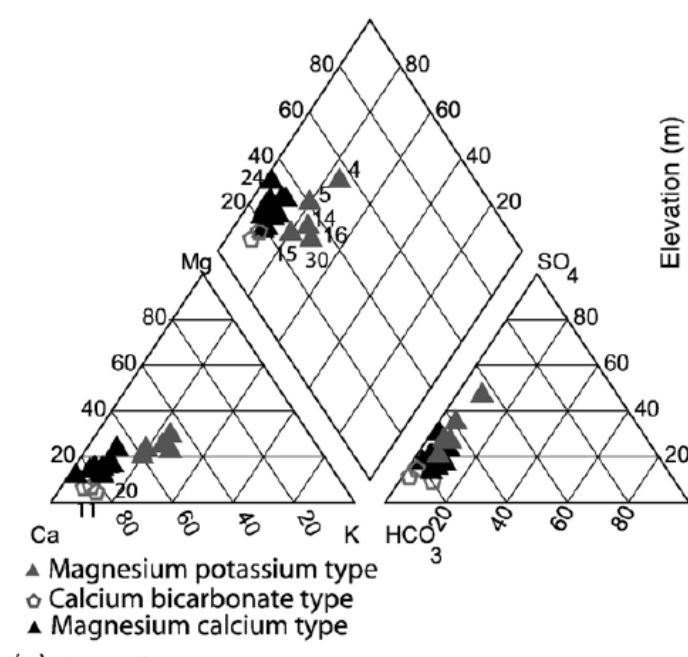

(a) Piper plot

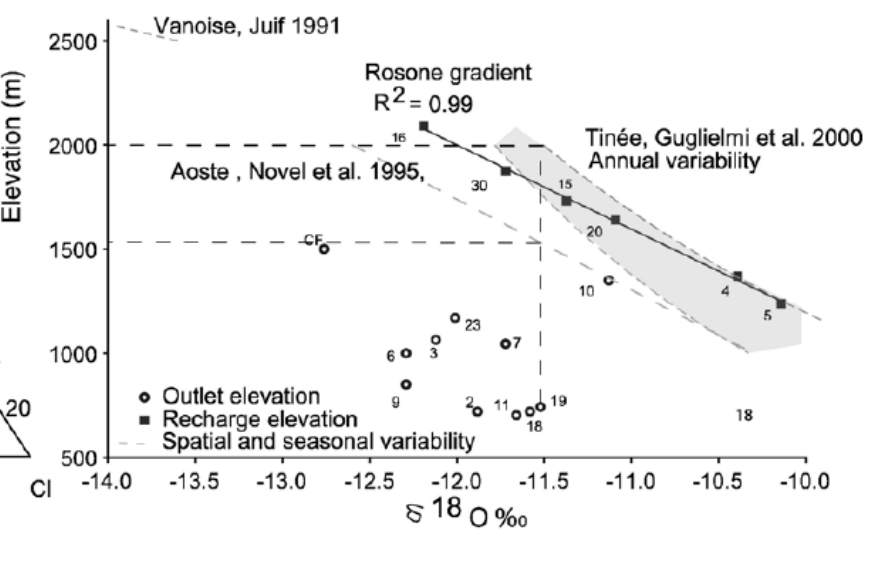

(b) Oxygen 18 versus elevation from the springs of the Rosone slope

Fig. 6. Water chemistry and isotopic measurements in the Rosone slope.

\begin{tabular}{|c|c|c|c|c|c|}
\hline \multirow[t]{2}{*}{$\begin{array}{l}\text { June } \\
2004\end{array}$} & $\delta^{18} \mathrm{O}$ & $\begin{array}{l}\text { Average elevation } \\
\text { of the infiltration } \\
\text { area (from } \delta^{18} \mathrm{O} \text { ) }\end{array}$ & $\begin{array}{l}\text { Low } \\
\text { water } \\
\text { yield }\end{array}$ & $\begin{array}{l}\text { Infiltration } \\
\text { area }\end{array}$ & $\begin{array}{l}\text { Infiltration } \\
\text { yield }\end{array}$ \\
\hline & $\%$ & $\mathrm{~m}$ & $\begin{array}{l}1 / \mathrm{s} \\
( \pm 20 \%)\end{array}$ & $\mathrm{km}^{2}$ & $\left(1 / \mathrm{s} / \mathrm{km}^{2}\right)$ \\
\hline \multicolumn{6}{|c|}{ References } \\
\hline S16 & -12.19 & 2090 & 0.20 & 0.05 & 4.3 \\
\hline S20 & -11.09 & 1640 & 0.15 & 0.05 & 3.0 \\
\hline S15 & -11.37 & 1730 & 0.21 & 0.08 & 2.8 \\
\hline S4 & -10.39 & 1370 & 0.38 & 0.11 & 3.4 \\
\hline
\end{tabular}

Tests of the infiltration area

$\begin{array}{lrllll}\text { S5 } & -10.14 & 1238 & 0.53 & 0.06 & 9.2 \\ \text { S5 } & -9.14 & 1238 & 0.53 & 0.17 & 3.1\end{array}$


Table 1:Water balance on the Rosone slope, with groundwater data from June 2004



Fig. 7. Frequencies of the transit time between infiltration periods and increase of water pressure, in the Bertodasco sector, for 100 precipitation events between 2000 and 2004.



Fig. 8. Hydrogeological cross section of the Rosone slope, with water head in boreholes and spring location. 


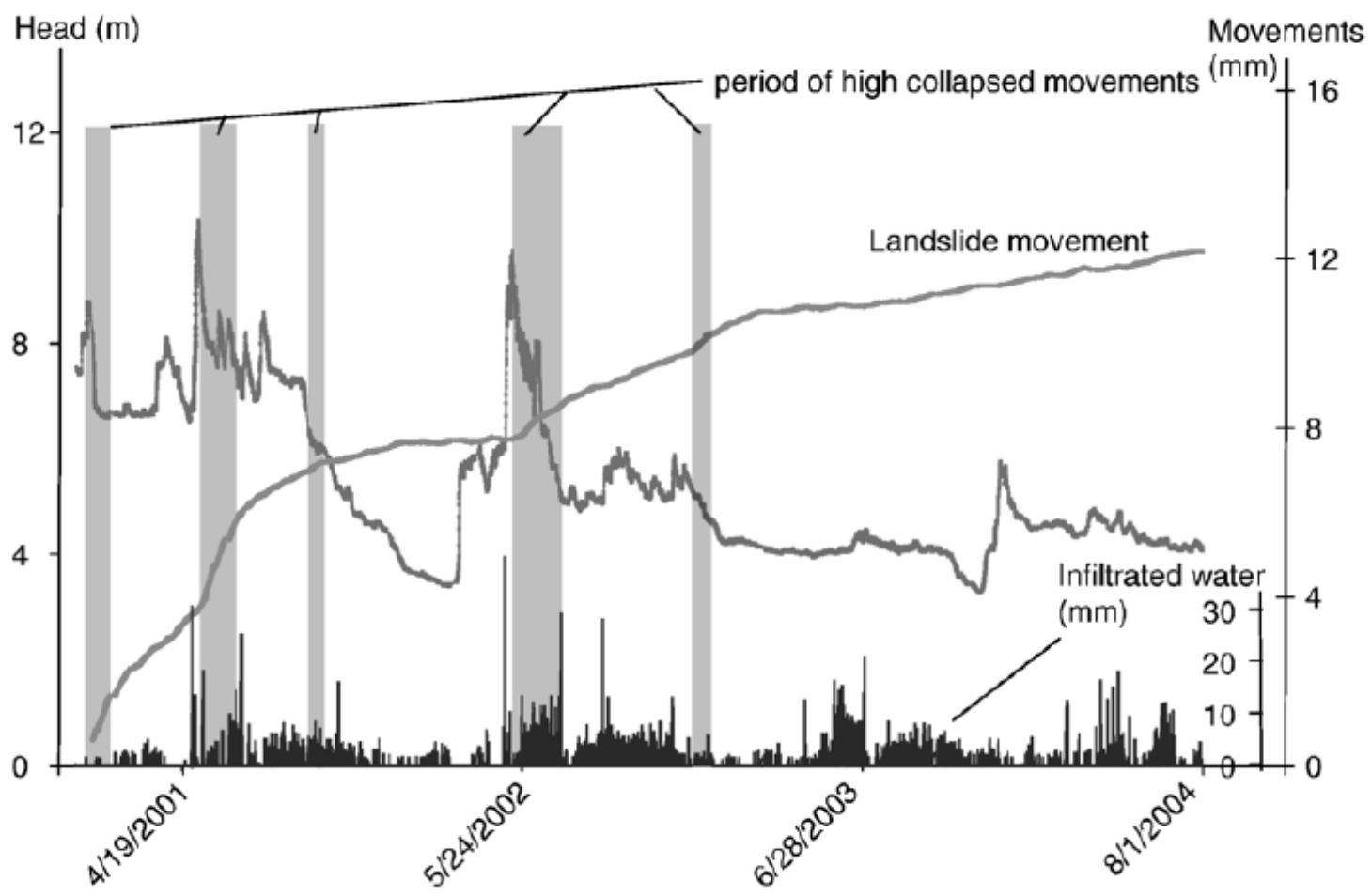

Fig. 9. Time head measurements in the B1 piezometer from 2000 to 2004.

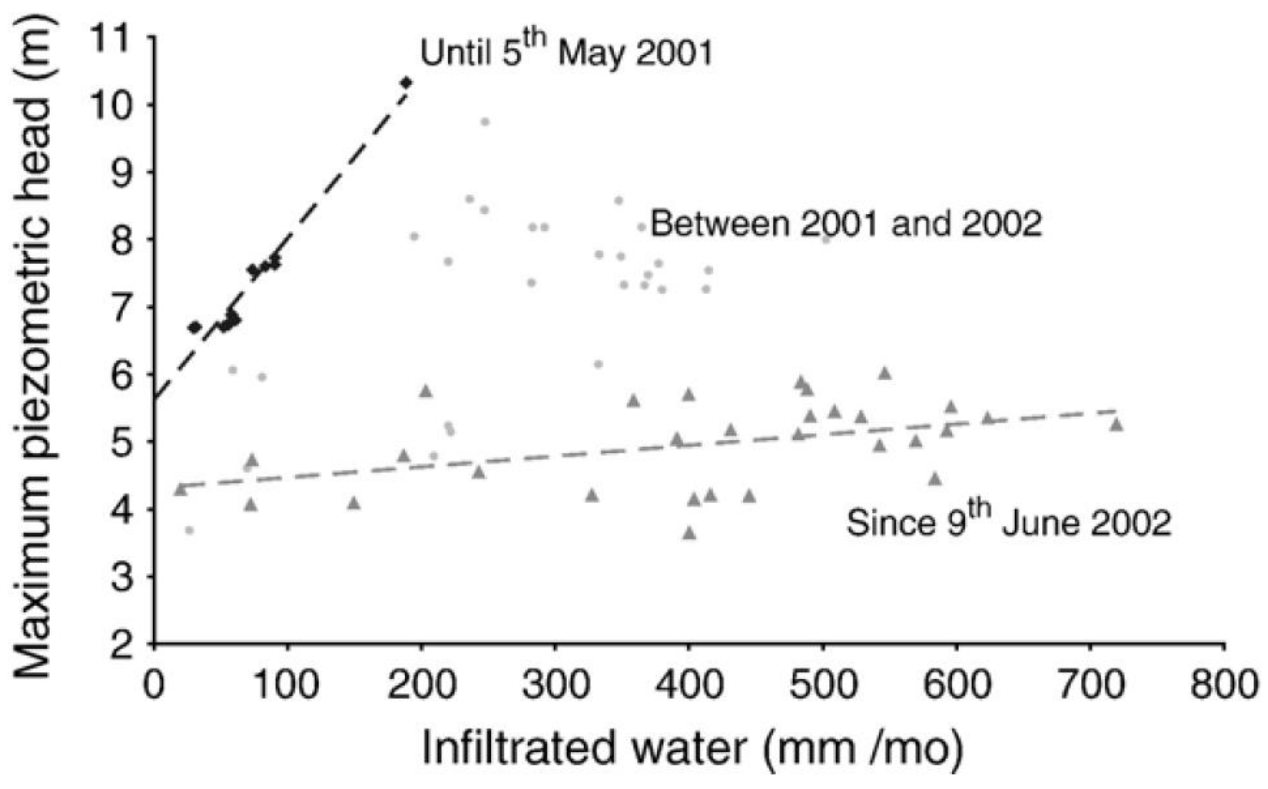

Fig. 10. In situ characterization of a flow-damage coupling phenomena. 